\title{
COMPETITIVENESS OF POLISH AGRICULTURE IN THE CONTEXT OF GLOBALIZATION AND ECONOMIC INTEGRATION - COMPETITIVE POTENTIAL AND POSITION
}

\author{
KAROLINA PAWLAK \\ WALENTY POCZTA
}

\begin{abstract}
The aim of the research presented in this paper is to assess the competitive potential of Polish agriculture (potential competitiveness) and the competitive position of the Polish agri-food sector on the Single European Market (SEM) with reference to the global context. The conducted research has proven that Polish agriculture, while having significant production potential (potential competitiveness) on a European scale, is at the same time characterized by the significant structural deficiencies of this potential, which may adversely affect he competitive position of Polish agriculture in the future. Poland's inclusion in the SEM area and the adoption of the rules of the Common Commercial Policy resulted in the creation and diversion of trade in agri-food products, and the comparative advantages achieved on the SEM became a source of favorable export specialization, allowing for relatively good use of the currently existing potential of agriculture and the food industry. This has resulted in the relatively good competitive position of the Polish agri-food sector on the SEM. However, in the long term, the ability to maintain or improve competitiveness in the future will be determined by competitive potential. The Polish agri-food sector has significant potential to increase exports and strengthen its competitive position (also on non-EU markets), provided that strong foundations for the sector are built, including an improvement in competitive potential.
\end{abstract}

Keywords: competitive potential, competitive position, foreign trade in agri-food products, European Union, globalization.

JEL codes: F10, F12, F13, F14, F15.

Karolina Pawlak, PhD, DSc, Assoc. Prof. of University of Life Sciences in Poznań, Faculty of Economics, ul. Wojska Polskiego 28, 60-637 Poznań (karolina.pawlak@up.poznan.pl). ORCID ID: 0000-0002-5441-6381. Walenty Poczta, PhD, DSc, ProfTit, University of Life Sciences in Poznań, Faculty of Economics, ul. Wojska Polskiego 28, 60-637 Poznań(walenty.poczta@up.poznan.pl). ORCID ID: 0000-0002-7592-7412. 


\section{Introduction}

Competitiveness derives from competition and is its element (Skawińska, 2002). In the conditions of a market economy, competition with other entities, understood as mutual rivalry aimed at achieving benefits related to operation on the 'domestic and international markets (Misala, 2007), is an inherent element of the operation of every economic entity and, at the same time, one of the basic mechanisms of the economy. The scope of such competition may vary, as competition exists on a regional, national, or international scale. Increased research into the competitiveness of enterprises, sectors, regions, or national economies is inextricably linked with the ongoing processes of integration, internationalization, and globalization that force the identification and measurement of the determinants of the competitiveness of entities operating on international markets and influence their economic policy. Globalization is changing the economic environment and causing a transition from territorially defined national economies to the open space of global economies (Woś, 2003), thus determining the course of the processes of competition. International economic policy pursued within international economic organizations, integration groups, as well as regional and interregional trade agreements, creates an environment in which the trade policy defined by the domestic situation is modified (Pawlak, 2013), contributing to the effective accomplishment of goals on the international market and enabling effective competition. The relationship between globalization and regional integration remains an important issue affecting international competitiveness. It is usually assumed that, on the one hand, regional integration may favor globalization and be regarded as a kind of stage or transition in the further spread of globalization (integration then becomes an essential feature of globalization), but on the other hand, regional integration may be treated as a form of defense and opposition against globalization processes (Milczarek, 2004; Kołodko, 2010).

In this context, the direction of research into competitiveness, established in the theory of international trade, in which competitiveness, understood as the ability to cope with international competition, manifests itself through the acceptance of a country's products by foreign markets and is defined as the ability to maintain or increase market share, becomes increasingly important (Agriculture Canada, 1991; van Duren, Martin and Westgren, 1991; Lubiński, 1995; Kennedy, Harrison, Kalaitzandonakes, Peterson and Rindfuss, 1997; Pitts and Lagnevik, 1998; Pawlak, 2013). In other words, assuming that competitiveness is manifested only on foreign markets, because only there is it assessed by numerous researchers (Wziątek-Kubiak, 2003), the phenomenon of competitiveness can be considered as "the ability of domestic companies to effectively and profitably establish themselves on foreign markets and develop effective exports" (Woś, 2000, 2001). The easures used to assess the level of this "external" competitiveness include the balance of trade, terms of trade, shares in world trade, and indices of comparative advantage. 
When analyzing international competitiveness, two concepts should be distinguished, i.e., international competitive position, also known as output competitiveness, and international competitive ability, often referred to as input competitiveness (Misala, 2007). International competitive position, referring mainly to the share of a given country's economy in international trade, is a concept narrower than international competitive ability, and it is considered by Bieńkowski (1995) to be merely an external, hence incomplete, manifestation of input competitiveness. Wziątek-Kubiak (1997) and Bieńkowski and Sadza (2000) point out that output competitiveness is interpreted as the ability to compete at a given moment and represents a static (synchronous) approach to competitiveness. As static research does not fully explain the sources of differentiation of the competitiveness of products on an international scale and over time, attempts are made to make the research more dynamic. The dynamic (diachronic) approach emphasizes not only the ability to compete at a certain point in time, but above all, the ability to compete in the long term, meaning the ability to maintain or improve competitiveness in the fture (Pawlak, 2013). In this case, the analysis of competitiveness is based on the variables that determine improvement in the competitive position, which can be defined as competitive potential.

Considering the essence of competitiveness, Buckley, Pass, and Prescott (1988) identify the following: competitive potential, related primarily to the availability of resources or factors of production, competitive position, i.e., competitive performance, and management process, defined as the optimal operation and use of available potential to achieve a certain competitive position. Using this terminology, it can be assumed that the competitiveness of an economy or its sector emerges as a result of a complex and dynamic interaction (feedback) between the three elements defined above.

Research into the competitiveness of agriculture primarily comes down to the assessment of the competitive ability of this sector, taking into account the quantity, quality, and efficient use of the factors of production and the relationships between them (Poczta and Pawlak, 2010, 2011; Baer-Nawrocka and Markiewicz, 2013; Jaroszewska and Rembisz, 2019). Research aimed at identifying the competitiveness of agri-food products on foreign markets is carried out frequently as well (Pawlak, 2017, 2018; Smutka, Maitah and Svatos, 2018; Szczepaniak, 2019). In both cases, the competitiveness of agriculture and its entities, and thus also of the food industry, is determined primarily by external factors falling within the broadly defined area of state activity and relating to the economic policy pursued by it, including intervention, fiscal, monetary, trade, innovation, and food safety policies (Nosecka, Pawlak and Poczta, 2011). An equally important role in developing the competitive position and ability of particular economies or their sectors is played by changes in the nature of international competition and changes in international trade policy (Pawlak, 2013), driven by ongoing processes of globalization and regional economic integration. 
Therefore, the aim of the research presented in the paper is to assess the competitive potential of Polish agriculture (potential competitiveness) and the competitive position of the Polish agri-food sector on the Single European Market with reference to the global context. Competitive potential was measured using the size of available land and labor resources as well as capital expenditure in agriculture in Poland and in the EU-28 compared to global agriculture, followed by an assessment of the status of the relationships between the factors of production in selected EU Member States. The analysis was completed with a study of the area and economic structure of farms in the EU Member States. The competitive position of the Polish agri-food sector on the SEM was examined in absolute and relative terms, using the values of trade and selected indices based on shares in trade, i.e., the Revealed Symmetric Comparative Advantage (RSCA) and Lafay's Trade Balance Index (TBI). Based on the calculated index values, the Widodo matrix was built, allowing for positioning of the analyzed product groups on the selected reference market ${ }^{1}$. Changes in the structure of farms and changes in foreign trade were analyzed in the periods of 2005-2016 and 1980-2018, sufficient to identify transformations in the Polish agrifood sector caused by changes in external conditions resulting from the ongoing processes of globalization and regional economic integration. The latest available data from the FAO, WTO, and Eurostat were used in detailed analyses of the competitive potential and position. In this way, an up-to-date image of the Polish agri-food sector's place on the SEM was obtained. It was possible both to quantify the potential held and the performance resulting from its use (competitive position) in the conditions of economic integration and globalization.

\section{Competitive potential of Polish agriculture}

According to FAO data, the production potential of agriculture on a global scale is accumulated in 570 million farms. About $92-98 \%$ of them are private farms, using about $56 \%$ of the total utilized agricultural area (UAA) in the world. As many as $72 \%$ of family farms, equated by the FAO with private farming, have UAA of less than 1 hectare and use only $8 \%$ of the utilized agricultural area in the world. Another $12 \%$ of such farms have an area of $1-2$ hectares and occupy $4 \%$ of the UAA. In total, $84 \%$ of farms use only $12 \%$ of the UAA, and the average area of these farms is 1.2 ha of UAA. On the other hand, $1 \%$ of farms use $65 \%$ of the utilized agricultural area. In the most developed countries, there are almost 22 million farms whose average area is 57 ha of UAA (in these countries, farms with an area of over 50 ha of UAA constitute $9 \%$ of all farms, but use as much as $82 \%$ of the UAA) (The State of Food..., 2014)2.

\footnotetext{
${ }^{1}$ For more information, see the section: Competitive position of Polish foreign trade in agri-food products.

${ }^{2}$ Every ten years since 1950, the FAO has been carrying out the FAO World Program for the Census of Agriculture (WCA) that consists in supporting underdeveloped countries in carrying it out. The presented data relates to the latest WCA carried out in 2010 that includes data for 2006-2015.
} 
EU agriculture uses only $3.8 \%$ of the world's agricultural land while accumulating $13.1 \%$ of the production assets, including more than a quarter of all machines and devices (Table 1). Similar volumes of production assets are accumulated in North American agriculture. Analyzing the ratio of the value of capital resources to land resources, it can be noticed that in EU agriculture there are more than three times more production assets per 1 ha of UAA than the global average, and twice as many as in North America. Only $1 \%$ of all economically active people in global agriculture are employed in agriculture in the EU and North America. In North American agriculture, one agricultural worker has at their disposal about 35 times more land and 50 times more production assets than the average in world agriculture. In EU agriculture, this asymmetry is less profound - compared to the global average, one worker has at their disposal almost 4 times more land resources and 13 times more production assets. The potential contained in the factors of production accumulated in EU agriculture, and the relationships between these factors, enable the production of $9.4 \%$ of all agricultural output on a global scale. This means that EU agriculture is characterized by 2.5 times greater land productivity and almo\$t 10 times greater labor productivity than the average in world agriculture.

Table 1

EU agriculture compared to world agriculture ${ }^{a}$

\begin{tabular}{lccc}
\hline \multicolumn{1}{c}{ Item } & World & North America & EU \\
\hline Utilized agricultural area - share (\%) & 100.0 & 9.7 & 3.8 \\
People economically active in agriculture - share (\%) & 100.0 & 0.3 & 1.0 \\
Production assets - share (\%) & 100.0 & 13.4 & 13.1 \\
$\quad$ - including machines and devices - share (\%) & 100.0 & 23.9 & 25.3 \\
Production factor ratios & & & \\
• UAA per 1 agricultural worker (ha) & 5.4 & 191.3 & 19.8 \\
• assets per 1 agricultural worker (USD thousand) & 5.8 & 294.8 & 75.1 \\
• assets per 1 ha of UAA (USD thousand) & 1.6 & 1.6 & 4.2 \\
$\begin{array}{l}\text { Value of agricultural output - share (\%) } \\
\text { (USD, fixed prices for 2014-2016 }\end{array}$ & 100.0 & 10.3 & 9.4 \\
Land productivity (USD/1 ha of UAA) & 855 & 913 & 2130 \\
$\begin{array}{l}\text { Labor productivity } \\
\text { (USD thousand/1 agricultural worker) }\end{array}$ & 4.6 & 174.6 & 42.4 \\
\hline
\end{tabular}

${ }^{a}$ the data included in the table, depending on their availability, cover 2010-2018.

Source: FAOSTAT 2020, World Bank 2020, Eurostat 2020, own calculations. 


\section{Resources of the factors of production in Polish agriculture and the relationships between them}

Compared to EU agriculture, Polish agriculture has significant production potential accumulated in resources of the factors of production. Particular attention should be paid to the significant (the largest in the EU) labor resources expressed in labor input (AWU) and large agricultural land resources (Table 2). Capital expenditures are clearly lower relative to land resources and labor input. Production resources in Polish agriculture are concentrated in a very large number of farms (in EU agriculture, only Romania has more farms than Poland).

Besides being affected by the absolute quantity of resources, the competitive potential of agriculture is also significantly influenced by the relationships between the main factors of production, i.e., labor, land, and capital. The ratios between resources of the factors of production may vary depending on a number of factors such as: land resources in total and per capita, weather conditions, the level of socio-economic development of the country, the size of the agricultural population, economic policy, and others. The quantity of resources of the factors of production and the relationship between them co-determine the type of agriculture, productivity of the factors of production, scale of production, and the degree of integration of agriculture with industry and agricultural trade (Baer-Nawrocka and Poczta 2016).

The place of Polish agriculture in EU agriculture in terms of production potential (resources of the factors of production and farms) (2016)

\begin{tabular}{lcc}
\hline \multicolumn{1}{c}{ Factor of production (resources or input) } & Position in EU-28 & Share in EU-28 (\%) \\
\hline Labor (in AWU) & 1 & 18.1 \\
Land (in UAA) & 5 & 8.3 \\
Capital & 7 & 5.2 \\
(production consumption plus depreciation in EUR) & Farms & 2 \\
Farms in total
\end{tabular}

Source: own calculations based on Eurostat data.

In order to assess the advantages of the relationships between the factors of production in Polish agriculture, it is important to compare them with the corresponding relationships in SEM countries, particularly with agriculture in countries where, due to weather conditions, there is a similar structure of agricultural production, i.e., with agriculture in Central, Western, and Northern Europe (Table 3). This comparison was made by designating three levels of relationship between resources or input of labor, land, and capital, where: (1) good relationship exceeds the average values in EU agriculture, (2) relationship in the range of average values, (3) relationship below the range of average values in EU agriculture. 
Table 3

Relationship between the factors of production in selected EU countries and assessment of their advantages (2016)

\begin{tabular}{|c|c|c|c|}
\hline \multirow[b]{2}{*}{ Country } & \multicolumn{3}{|c|}{ Relationships between resources and factor input } \\
\hline & $\begin{array}{l}\text { UAA per } 1 \text { AWU } \\
\text { (ha) } \\
<\mathbf{1 0 ;} \mathbf{1 0 - 3 0 ; > 3 0}\end{array}$ & $\begin{array}{l}\text { Capital outlays per } 1 \text { AWU } \\
\text { (EUR thousand) } \\
<15 ; \mathbf{1 5 - 5 0 ; ~}>\mathbf{5 0}\end{array}$ & $\begin{array}{c}\text { Capital outlays per } 1 \text { ha of UAA } \\
\text { (EUR thousand) } \\
<1.2 ; 1.2-2.2 ;>2.2\end{array}$ \\
\hline EU-28 & 19.2 & 33.1 & 1.7 \\
\hline Belgium & 24.5 & 123.7 & 5.1 \\
\hline Bulgaria & 18.0 & 10.8 & 0.6 \\
\hline Czech Rep. & 33.5 & 37.7 & 1.1 \\
\hline Denmark & 52.8 & 182.8 & 3.5 \\
\hline France & 39.3 & 75.0 & 1.9 \\
\hline Greece & 10.2 & 14.5 & 1.4 \\
\hline Spain & 29.0 & 33.2 & 1.1 \\
\hline Netherlands & 12.2 & 142.6 & 11.7 \\
\hline Ireland & 30.4 & 37.4 & 1.2 \\
\hline Germany & 34.1 & 93.4 & 2.7 \\
\hline Poland & 8.7 & 9.6 & 1.1 \\
\hline Portugal & 11.6 & 16.7 & 1.4 \\
\hline Romania & 7.9 & 8.0 & 1.0 \\
\hline Slovakia & 40.5 & 41.5 & 1.0 \\
\hline Hungary & 11.9 & 14.8 & 1.2 \\
\hline Italy & 14.4 & 39.9 & 2.8 \\
\hline
\end{tabular}

Color marking: green - good relationship, no color - relationship in the range of average values, red - relationship below the range of average values.

Source: own calculations based on Eurostat data.

EU agriculture varies quite significantly in terms of the status of the relationships between factors of production. Agriculture in countries such as Denmark and Germany is characterized by above-average relationships between the factors of production at all three levels of analysis, i.e., one agricultural worker has at their disposal much higher-than-average land and capital resources, and the level of capital expenditure per unit of land resources also clearly exceeds the average values. In French agriculture, one worker also has at their disposal above-average land and capital resources, but the level of capital expenditure per 1 ha of UAA is average. On the other hand, in Belgian and Dutch agriculture, one agricultural worker has at their disposal average land resources, but the level of their capital resources is above average, and so is the level of capital expenditure per 1 ha of UAA. In the vast majority of new Member States, the capital resources available to agricultural workers are clearly below the average, and so is the capital expenditure per 1 ha of UAA. 
The worst relationships between the factors of production are recorded in Romanian and Polish agriculture. The relationship illustrating the availability of the active factor of production, i.e., labor, in the production process shows the poor competitive situation of Polish agriculture in terms of competitive potential and determines the low labor productivity in this sector ${ }^{3}$. The relatively low intensity of agricultural production (the ratio of capital expenditure to land resources) determines the relatively low land productivity. Among the analyzed countries, besides Romanian agriculture mentioned above, Polish agriculture is also characterized by significantly worse ratios in all three analyzed relationships. This is undoubtedly one of the factors already worsening the competitive potential of Polish agriculture, but more importantly, it may have a negative impact on the competitive position of Polish agriculture in the future.

\section{Area structure of farms}

Being inextricably linked with the resources of the factors of production (especially land), agricultural activity depends heavily on production structures, which in turn determine the efficiency of its operation and its competitiveness worldwide. In the conditions of globalization of the world economy, the competitiveness of national economies and their sectors is determined to a large extent by having production structures equipped with capital resources and managed by people open to changes in technological processes, as well as assimilating and implementing innovations. In agriculture, these are farms.

Analysis of the evolution of the structures of EU agriculture from 2005-2016 shows that the total number of farms is decreasing, but the decrease in their number is recorded only in groups of farms with a small land area and economic size. In each Member State, there are area and economic size groups ("threshold groups") that are specific "turning points" 4 . In the threshold and higher-level groups, the number of farms is increasing. Without going into the variety of detailed reasons for closing down and establishing farms, as well as for increasing and reducing their production potential, it was concluded that in most cases these reasons are economic ones. The reduction in the number of farms in "subthreshold groups" is therefore the result of the view that running farms with an area and/or economic size below a certain level does not generate income acceptable to farm owners or their possible successors. On the other hand, the increase in the number of threshold and higher-level groups proves that running farms in a specific area and/or generating output at the threshold level is still considered a profitable economic activity worth developing and investing in (Czubak, Poczta, and Rowiński, 2019).

\footnotetext{
${ }^{3}$ According to Eurostat data, labor productivity in Polish agriculture, measured using the output volume per $1 \mathrm{AWU}$, is only $33 \%$ of the average in EU agriculture, while land productivity is $73 \%$.

${ }^{4}$ Threshold values were determined according to the methodology proposed by J. Rowiński and excerpts from the study: Czubak et al., 2019.
} 
Table 4

Area thresholds in Member States from 2005-2016a

\begin{tabular}{lclc}
\hline \multicolumn{1}{c}{ Member State } & Threshold (ha) & \multicolumn{1}{c}{ Member State } & Threshold (ha) \\
\hline 1. Hungary & $10-19.9$ & 11. Italy & $50-99.9$ \\
2. Ireland & $10-19.9$ & 12. Sweden & 100 or more \\
3. Romania & $20-29.9$ & 13. Portugal & 100 or more \\
4. Slovenia & $20-29.9$ & 14. France & 100 or more \\
5. Poland & $\mathbf{3 0 - 4 9 . 9}$ & 15. Germany & 100 or more \\
6. Latvia & $50-99.9$ & 16. Spain & 100 or more \\
7. Lithuania & $50-99.9$ & 17. Belgium & 100 or more \\
8. Netherlands & $50-99.9$ & 18. Finland & 100 or more \\
9. Austria & $50-99.9$ & 19. United Kingdom & 100 or more \\
10. Estonia & $50-99.9$ & 20. Denmark & 100 or more \\
\hline
\end{tabular}

The analysis does not include the Czech Republic, Slovakia, and Bulgaria, because in these countries, ca. $90 \%$ of UAA is located on farms with an area of 100 ha or more. In Greece and Cyprus, it was not possible to set the threshold, because the number of farms decreased in all groups. The analysis does not include Luxembourg, Malta, and Croatia.

Source: Czubak at al. (2019).

Table 4 shows the area thresholds for the 20 Member States for which area thresholds have been set. The area group listed as a threshold is the group with the smallest area in which the number of farms increased. The area threshold speaks to the fact that some farmers consider farming on a smaller area to generate such low income that it is reasonable to give up farming.

In nine out of twenty countries included in Table 4, the minimum area of a farm generating satisfactory income is $100 \mathrm{ha}$, and in another six, it is 50 ha. Only in five countries, including Poland, are the thresholds at levels below 50-100 ha. Besides Ireland, these are "new" Member States with a significant number of farms with an area below 10 ha of utilized agricultural area. The threshold "set" by Polish farmers is consistent with the opinions of numerous Polish agricultural economists based on detailed calculations, as well as with the findings of the Polish FADN (Czubak et al., 2019).

\section{Economic structure of farms}

Economic size thresholds were set in a similar way (Table 5). Except Latvia, in all "new" Member States examined, the thresholds were very low. In the analyzed period, there was a clear dividing line between the "old" and "new" EU Member States (Czubak et al., 2019). The "old" states had thresholds higher than all states in Central and Eastern Europe (except for Latvia). In most of the "old" Member States, there is a clear tendency to concentrate agricultural production in agricultural enterprises or entities in between family farms and enterprises (standard output of more than EUR 100 or 250 or even 500 thousand per year). 
To sum up, Polish agriculture, with its significant production potential on a European scale, is at the same time characterized by significant structural deficiencies of this potential. Without underestimating the importance of all other determinants of competitiveness, it can be said that the scale of this potential and its structural efficiency will be one of the key determinants of the competitiveness of Polish agriculture in the future.

Table 5

Economic size thresholds in Member States from 2005-2016

\begin{tabular}{lclc}
\hline \multicolumn{1}{c}{ Member State } & Threshold (EUR) & \multicolumn{1}{c}{ Member State } & Threshold (EUR) \\
\hline 1. Bulgaria & $8,000-14,999$ & 12. Portugal & $50,000-99,999$ \\
2. Romania & $8,000-14,999$ & 13. Italy & $50,000-99,999$ \\
3. Lithuania & $15,000-24,999$ & 14. Sweden & $100,000-249,999$ \\
4. Hungary & $15,000-24,999$ & 15. Finland & $100,000-249,999$ \\
5. Slovenia & $15,000-24,999$ & 16. France & $100,000-249,999$ \\
6. Estonia & $25,000-49,999$ & 17. Spain & $100,000-249,999$ \\
7. Poland & $\mathbf{2 5 , 0 0 0 - 4 9 , 9 9 9}$ & 18. Germany & $250,000-499,999$ \\
8. Greece & $25,000-49,999$ & 19. Belgium & $250,000-499,999$ \\
9. Latvia & $50,000-99,999$ & 20. United Kingdom & $250,000-499,999$ \\
10. Ireland & $50,000-99,999$ & 21. Netherlands & $250,000-499,999$ \\
11. Austria & $50,000-99,999$ & 22. Denmark & 500,000 or more \\
\hline
\end{tabular}

The Czech Republic and Slovakia were not included in the analysis, as in these countries very large farms prevail. The analysis does not include Luxembourg, Cyprus, Malta, and Croatia.

Source: Czubak at al. (2019).

\section{Competitive position of the Polish agri-food sector}

\section{Turnover, dynamics, and importance of Polish foreign trade in agri-food products}

From 1980-2018, the value of world exports of agri-food products increased 6-fold, reaching USD 1.8 trillion (Table 6). Taking into account both the value of intra-Community trade and trade with third countries, almost $38 \%$ of world trade in agri-food products were carried out by EU countries. If, however, trade within the Single European Market is excluded from this count, the EU share in global agricultural exports in 2019 was slightly over $10 \%$ and was less than 1 percentage point higher than that of the Association of South East Asian Nations (ASEAN), 2 percentage points higher than that of the Southern Common Market (Mercado Común del Sur - MERCOSUR), but 4 percentage points lower than that of the North American Free Trade Agreement (NAFTA) and 5 percentage points lower than the combined shares of the ASEAN countries, China, Japan and South Korea (UNCTADstat, 2020). 
Table 6

Trade in agri-food products in the world, the EU, and Poland from 1980-2018 (USD billion)

\begin{tabular}{|c|c|c|c|c|c|}
\hline Item & 1980 & 1990 & 2000 & 2010 & 2018 \\
\hline \multicolumn{6}{|c|}{ World } \\
\hline Exports & 298.8 & 414.7 & 551.8 & $1,150.90$ & $1,806.90$ \\
\hline Imports & 312.2 & 442.9 & 598.8 & $1,158.20$ & $1,831.40$ \\
\hline Balance & -13.4 & -28.2 & -47 & -7.3 & -24.5 \\
\hline \multicolumn{6}{|c|}{ European Union } \\
\hline Exports & 98 & 175.8 & 230.4 & 469 & 681.2 \\
\hline Imports & 133.9 & 208.5 & 253.7 & 462.1 & 686.5 \\
\hline Balance & -36 & -32.7 & -23.3 & -6.9 & -5.3 \\
\hline \multicolumn{6}{|c|}{ Poland } \\
\hline Exports & 1.6 & 2.3 & 3.1 & 17.1 & 37.1 \\
\hline Imports & 3.7 & 1.3 & 4 & 13.5 & 26.3 \\
\hline Balance & -2.1 & 1 & -0.9 & 3.6 & 10.8 \\
\hline \multicolumn{6}{|c|}{ Shares in world trade $(\%)$ - European Union } \\
\hline Exports & 32.8 & 42.4 & 41.8 & 40.8 & 37.7 \\
\hline Imports & 42.9 & 47.1 & 42.4 & 39.9 & 37.5 \\
\hline \multicolumn{6}{|c|}{ Shares in world trade $(\%)$ - Poland } \\
\hline Exports & 0.5 & 0.5 & 0.6 & 1.5 & 2.1 \\
\hline Imports & 1.2 & 0.3 & 0.7 & 1.2 & 1.4 \\
\hline
\end{tabular}

Source: own research based on data from the WTO Data Portal.

The growth of Polish foreign trade in agri-food products was largely determined by Poland's inclusion in the SEM area and the adoption of acquis communautaire in the area of commercial policy. From 2004-2019, the value of exports of agrifood products from Poland increased almost 6-fold, and the value of imports increased 5-fold, reaching EUR 31.5 and EUR 21.1 billion, respectively, in the last analyzed year (Fig. 1). The trade surplus amounted to EUR 10.4 billion and was over 12 times higher than in the year of Poland's accession to the EU. The strength of the trade creation effect, resulting from the reduction in trade barriers within the SEM, is confirmed by the agri-food trade growth indicators in Poland in the decade from 2000-2010. The value of exports of agri-food proucts from Poland increased in this period more than 5.5-fold, with a 3.5 -fold increase in imports, compared to the approximately 2 -fold increase in the value of exports and imports in the EU and on average in the world (Table 7). Changes in Polish foreign trade policy in the first decade of the $20^{\text {th }}$ century clearly influenced the dynamics of trade in the agri-food sector from 1980-2018. This was particularly apparent in the case of exports, as the value of exports from Poland increased 23 -fold, 
while the value of exports from the EU increased in this period almost 7-fold, and about 6-fold globally. As a result, in 2018, Poland was the $14^{\text {th }}$ largest exporter and the $17^{\text {th }}$ largest importer of agri-food products in the world (Figure 2 and Figure 3). In the EU, in 2019 , the Polish agri-food sector was $7^{\text {th }}$ in terms of export value, behind the Netherlands, Germany, France, Spain, Italy, and Belgium, but ahead of the United Kingdom, Denmark, Ireland and Austria, and $3^{\text {rd }}$ in terms of the value of the generated trade surplus, behind the Netherlands and Spain, but ahead of France, Denmark, Belgium and Ireland (Comext-Eurostat, 2020). The export intensity per 1 ha of UAA was, however, still low.

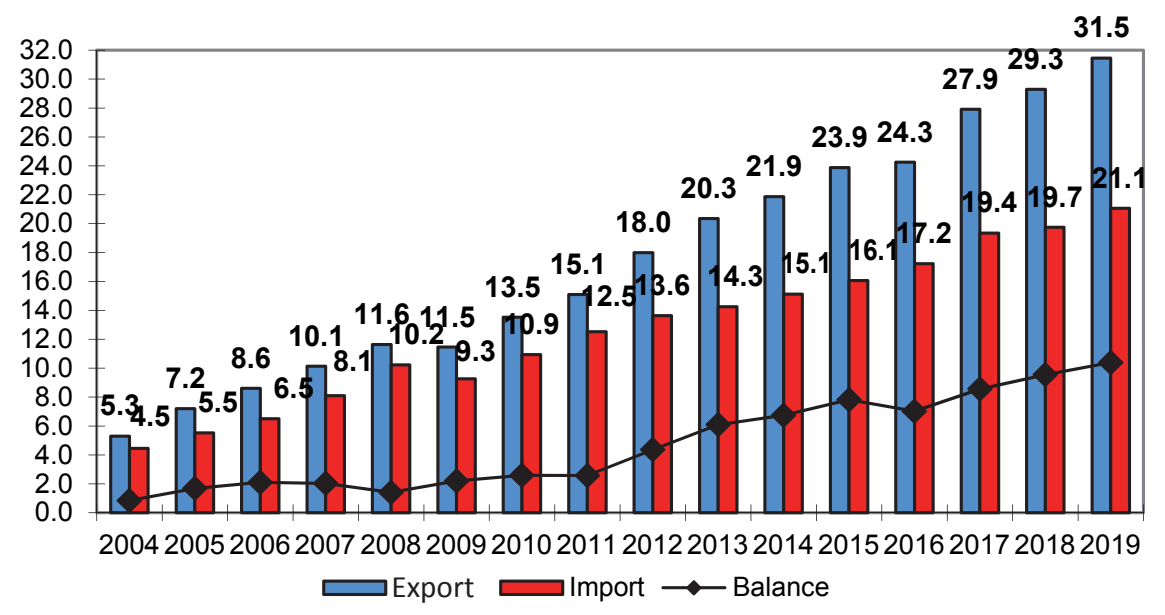

Fig. 1. Polish foreign trade in agri-food products from 2004-2019 (EUR billion)

Source: own research based on data from Comext-Eurostat.

The dynamics of trade in agri-food products in the world, the EU,

Table 7 and Poland from 1980-2018 (\%)

\begin{tabular}{|c|c|c|c|c|c|}
\hline Item & $1990 / 1980$ & $2000 / 1990$ & $2010 / 2000$ & $2018 / 2010$ & $2018 / 1980$ \\
\hline \multicolumn{6}{|c|}{ World } \\
\hline Exports & 138.8 & 133.1 & 208.6 & 157.0 & 604.7 \\
\hline Imports & 141.9 & 135.2 & 193.4 & 158.1 & 586.6 \\
\hline \multicolumn{6}{|c|}{ European Union } \\
\hline Exports & 179.5 & 131.0 & 203.6 & 145.2 & 695.1 \\
\hline Imports & 155.7 & 121.7 & 182.1 & 148.6 & 512.7 \\
\hline \multicolumn{6}{|c|}{ Poland } \\
\hline Exports & 142.0 & 136.6 & 551.8 & 217.0 & 2318.8 \\
\hline Imports & 33.8 & 315.2 & 341.8 & 194.8 & 710.8 \\
\hline
\end{tabular}

Source: own research based on data from the WTO Data Portal. 


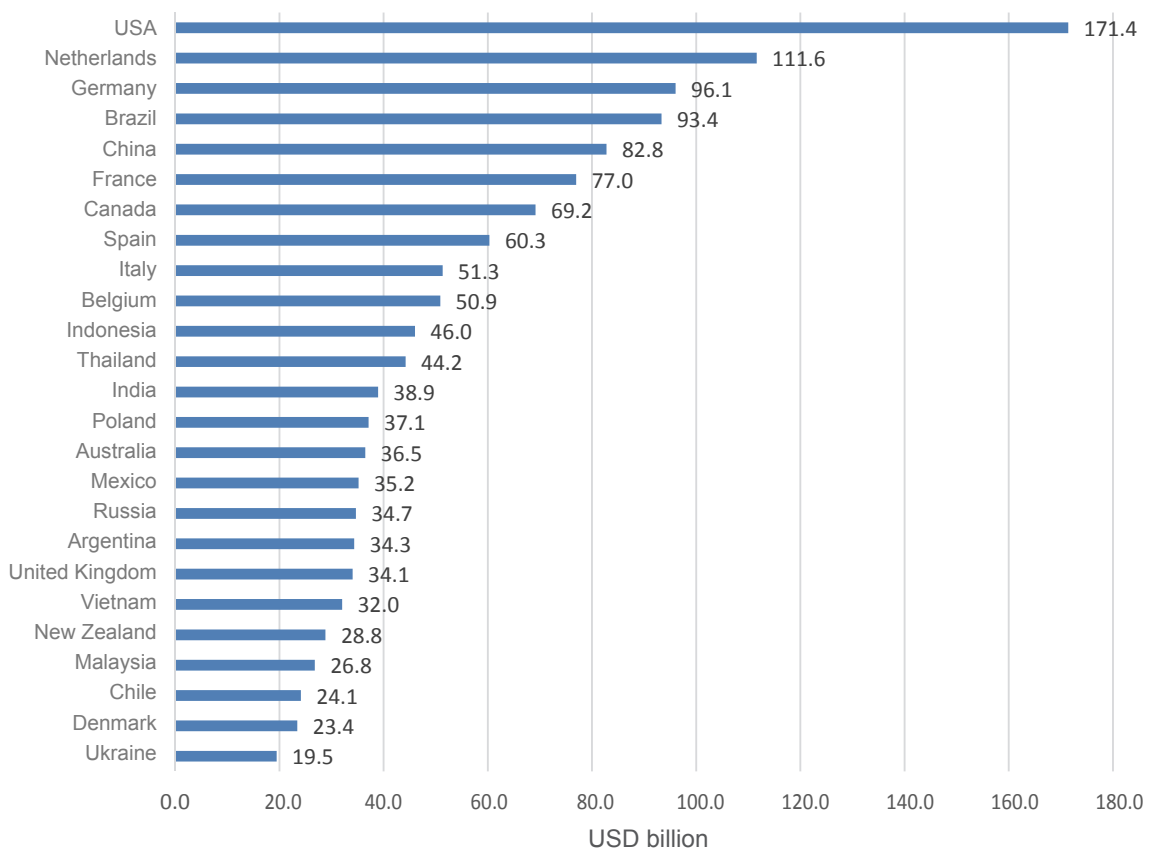

Fig. 2. The largest exporters of agri-food products in the world in 2018 (USD billion). Source: own research based on data from the WTO Data Portal.

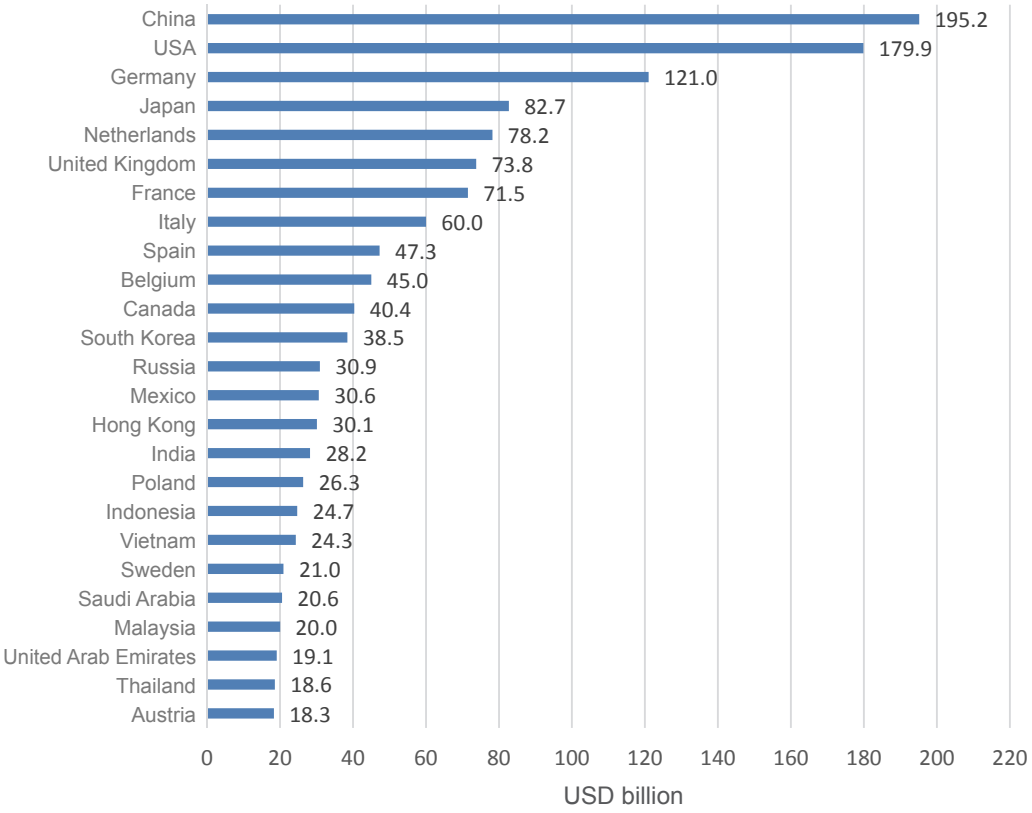

Fig. 3. The largest importers of agri-food products in the world in 2018 (USD billion). Source: own research based on data from the WTO Data Portal. 
Following Poland's accession to the EU, exports have become an important determinant of the equilibrium on agricultural markets, influencing the situation in many sectors of the food industry, in particular, the fishing industry, tobacco industry, coffee and tea processing as well as confectionery, that are geared to export and sell over $50 \%$ of their output on foreign markets. Moreover, in the tobacco and confectionery industries, as well as in the meat, dairy, and vegetable industries, exports helped break the internal demand barrier, while imports enabled not only better use of production potential and an improvement in the competitiveness of a number of industries (e.g., in the processing of fish, fruit and vegetables, coffee, cocoa, chocolate, and spices), but also an increase in consumption, improvement in the quality of food for society, and intensification of exports (Pawlak, 2014; op. cit.: Seremak-Bulge and Łopaciuk, 2011).

In 2019, the most important agri-food products exported from Poland to the markets of other EU countries were meat and offal, fish and seafood, preparations of meat and fish, dairy products, preparations of cereals, cocoa and cocoa products, vegetables, fruit, and processed fruit and vegetables, as well as tobacco and tobacco products. In total, the above-mentioned product groups accounted for over $70 \%$ of the total revenue generated by Poland from food exports (Comext-Eurostat, 2020).

\section{Competitive position of Polish foreign trade in agri-food products}

The competitive position of the most important groups of goods in Polish exports of agri-food products was determined by means of the Widodo method, using the matrix proposed by the authors. The Widodo matrix (Figure 4) enables the identification of four scenarios for the competitive position of a given country, differing in the level of generated comparative advantage (RSCA) and the degree of export specialization (TBI). The Revealed Symmetric Comparative Advantage (RSCA) index is a modification of Balassa's standard Revealed Comparative Advantage (RCA) index and is calculated according to the following formula:

$$
R S C A_{i j}=\left(R C A_{i j} j-1\right) /\left(R C A_{i j}+1\right) .
$$

Its values may be in the range of $[-1,1]$, where values lower than zero mean the $a b-$ sence of comparative advantage, while those above zero mean that such an advantage exists. The transformation of the asymmetrical RCA index with no finite upper limit was carried out by Laursen (1998) as well as Dalum, Laursen, and Villumsen (1998), and although it does not bring any interpretative advantages (De Benedictis and Tamberi, 2002), combined with Lafay's Trade Balance Index (TBI) it can be used to develop a matrix enabling synthetic assessment of the competitive position of particular countries with regard to trade in specific products or groups of products on selected benchmark markets (Widodo, 2009). The TBI index takes values in the range of $[-1,1]$ and is calculated according to the following formula:

$$
T B I_{i j}=\left(X_{i j}-M_{i j}\right) /\left(X_{i j}+M_{i j}\right) \text {. }
$$




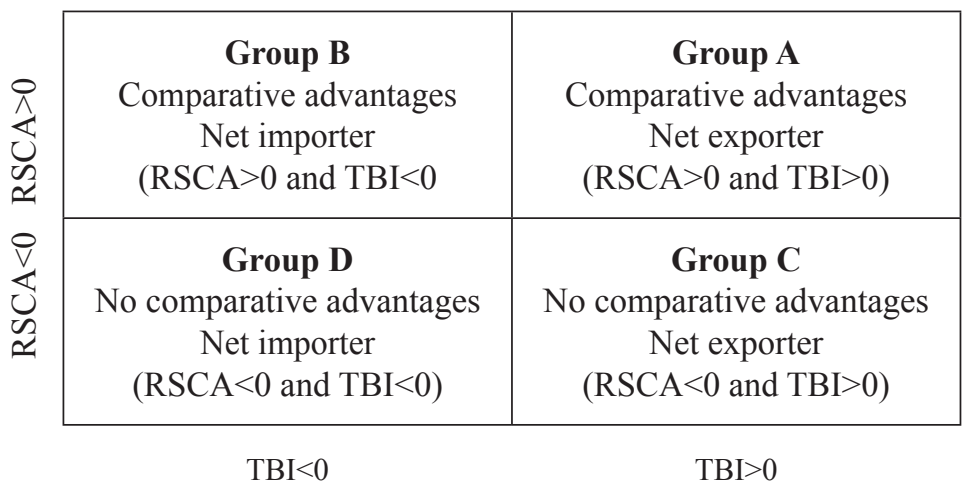

Fig. 4. Positioning of products by the level of comparative advantage and the degree of export specialization using the Widodo method.

Source: Widodo (2009).

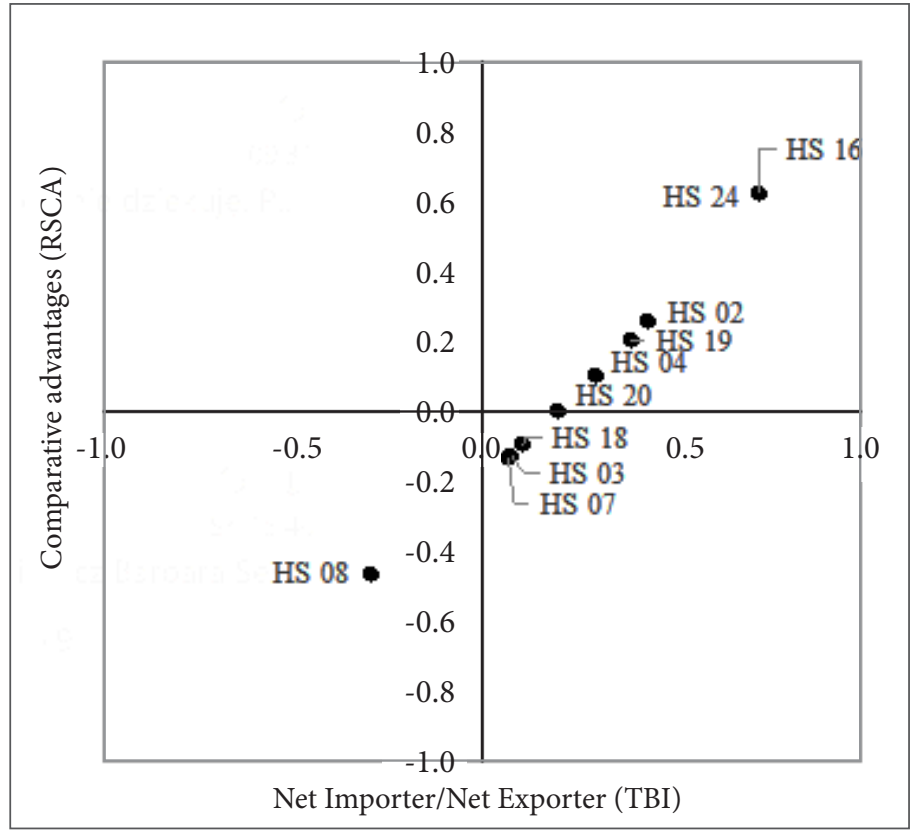

Fig. 5. Positioning of selected groups of agri-food productsa exported from Poland to the markets of other EU countries according to the level of their comparative advantages and the degree of export specialization in 2019 (Widodo method).

The study covers groups of products whose share in the structure of intra-Community exports in 2019 was at least $3 \%$, i.e., meat and edible meat offal (HS 02); fish, crustaceans, and molluscs (HS 03); dairy products, bird eggs, and natural honey (HS 04); vegetables (HS 07); fruit and nuts (HS 08); preparations of meat and fish (HS 16); cocoa and cocoa preparations (HS 18); preparations of cereals (HS 19); preparations of vegetables and fruit (HS 20), tobacco and tobacco products (HS 24)

Source: own research based on data from Comext-Eurostat. 
Positive values of the index denote the export specialization of the analyzed country and usually mean a trade balance surplus, while negative values indicate a lack of specialization and the country's position as a net importer of a given product or group of products (Lafay, 1992). Using the Widodo method provides an answer to the question whether the range of export goods follows the principle of comparative costs and whether it can be considered rational from this point of view.

Positioning of products according to the level of comparative advantage (RSCA) and the degree of export specialization (TBI) using the Widodo method showed that in 2019, Poland generated high comparative advantage on the SEM and a positive balance of trade in meat and meat offal (HS 02), preparations of meat (HS 16), dairy products (HS 04), preparations of cereals (HS 19) and tobacco products (HS 24; Figure 5).

The groups of products in which Poland generated the greatest comparative advantages and of which it was a net exporter (group A) accounted for over 50\% of the total exports of agri-food products to the markets of other EU countries, providing a trade surplus of EUR 11.0 billion, $6 \%$ higher than the positive result of the total balance of trade with EU countries (Table 8).

In intra-Community trade in fish (HS 03), vegetables (HS 07), preparations of vegetables and fruit (HS 20), and cocoa and cocoa preparations (HS 18), Poland did not have comparative advantage, but was a net exporter (group C), and exports of the above-mentioned groups of products accounted for ca. 19\% of the total revenue from exports of agri-food products to the SEM. A lack of comparative advantages was accompanied by a lack of export specialization and a trade deficit (group D) only in intra-Community trade in fruit (HS 08).

Table 8

Shares of particular product groups resulting from positioning using the Widodo method in Polish agri-food trade with other EU countries and the balance of trade in these groups in $2019(\%)^{a}$

\begin{tabular}{|c|c|c|c|c|}
\hline Group & HS codes & $\begin{array}{c}\text { Share } \\
\text { in exports } \\
\text { total }(\%)\end{array}$ & $\begin{array}{c}\text { Share } \\
\text { in imports } \\
\text { total }(\%)\end{array}$ & $\begin{array}{c}\text { Balance } \\
\text { (EUR million) }\end{array}$ \\
\hline Group A & HS 02, HS 04, HS 16, HS 19, HS 24 & 50.4 & 23.0 & $11,000.3$ \\
\hline Group B & . & . & . & . \\
\hline Group C & HS 03 , HS 07, HS 18, HS 20 & 18.9 & 24.5 & 771.2 \\
\hline Group D & HS 08 & 3.6 & 8.6 & -678.9 \\
\hline
\end{tabular}


Based on the conducted analyses, it can be concluded that the inclusion of Poland in the SEM area and the adoption of the rules of the Common Commercial Policy resulted in creation and diversion of trade in agri-food products, and the comparative advantages generated on the SEM were the source of favorable export specialization. Poland had a weaker competitive position in trade in products that, while being export specializations, also had to be imported for various reasons. The need to import products to meet the needs of the domestic market is not, however, tantamount to a definite negative assessment that a given range of products lacks competitiveness. In light of the above, the product structure of Polish foreign trade in agri-food with other EU countries can be considered rational. The Polish agri-food sector has a significant potential to increase exports. In view of the ongoing processes of globalization and (inter)regional liberalization of trade, the Polish agri-food sector is being offered opportunities to gain easier access to many non-EU markets. Due to the high level of concentration of turnover on the SEM (ca. $80 \%$ of Poland's trade is carried out with other EU countries), it can be assumed that the chances of further increasing the share of the Polish agrifood sector in this market are very limited. Therefore, the challenge is to diversify target markets and strengthen the positioning of Polish foreign trade on the markets of non-EU countries.

\section{Conclusion}

The increasing processes of globalization and integration are changing the economic environment. On the one hand, they are a source of institutional factors externally determining the course of the processes of competition on regional and international markets, and on the other, they force the measurement of more broadly defined internal and external determinants of competitiveness of the assessed entities and stimulate actions aimed at optimal use of their potential to achieve a certain competitive position. The aim of the research presented in the paper is to assess the competitive potential of Polish agriculture (potential competitiveness) and the competitive position of the Polish agri-food sector on the Single European Market in the global context. The analyses presented in the paper demonstrate the relatively good competitive position of the Polish agri-food sector on the SEM. Poland's inclusion in the SEM area and the adoption of the rules of the Common Commercial Policy resulted in the creation and diversion of trade in agri-food products, and the comparative advantages achieved on the SEM became a source of favorable export specialization, allowing for relatively good use of the currently existing potential of agriculture and the food industry. However, in the dynamic approach, aside from the ability to compete at a specific point in time, the ability to compete in the long term - i.e., the ability to maintain or improve competitiveness in the future - is of great importance, and this is determined by competitive potential. Polish agriculture has significant competitive potential on a European scale, contained primarily in land and labor resources. The potential competitiveness of Polish agriculture is significantly reduced by the structural deficiencies 
of the production potential. Due to the very high level of concentration of turnover on the SEM (ca. $80 \%$ of Poland's trade is carried out with other EU countries), it can be assumed that the chances of a further increase in the share of the Polish agri-food sector in this market are very limited. Hence, the institutional conditions, which are one of the fundamental sources of the good competitive position of Polish foreign trade on the SEM, will be gradually exhausted. Equally importantly, they will not be able to act as a stimulus for its expansion on non-EU markets. Therefore, the scale of the potential and its structural efficiency will be one of the key determinants of the competitiveness of Polish agriculture in the future. This applies to improvement in the competitive position on the SEM, but - above all - is a condition for building a good competitive position of the Polish agri-food sector on non-EU markets. To sum up, the Polish agri-food sector has significant potential to increase exports and strengthen its competitive position, provided that strong foundations for the sector are built, including an improvement in competitive potential. 


\section{References}

Agriculture Canada. Task Force on Competitiveness in the Agri-Food Industry (1991). Growing Together: Report to Ministers of Agriculture. Ottawa: Agriculture Canada.

Baer-Nawrocka, A., Markiewicz N. (2013). Relacje między czynnikami produkcji a efektywność wytwarzania w rolnictwie Unii Europejskiej. Journal of Agribusiness and Rural Development, 3, 5-16.

Baer-Nawrocka, A., Poczta, W. (2016). Polskie rolnictwo na tle rolnictwa UE. In: J. Wilkin, I. Nurzyńska (ed.), Polska Wieś 2016. Raport o stanie wsi. Warszawa: FDPA, Wyd. Scholar.

Bieńkowski, W. (1995). Reaganomika i jej wplyw na konkurencyjność gospodarki amerykańskiej. Warszawa: Wydawnictwo Naukowe PWN.

Bieńkowski, W., Sadza, P. (2000). Rola instytucji w poprawie konkurencyjności gospodarki-zadania dla rządu. In: H. Podedworny, J. Grabowiecki, H. Wnorowski (ed.), Konkurencyjność gospodarki polskiej a rola państwa przed akcesją do Unii Europejskiej. Białystok: Wydawnictwo Uniwersytetu w Białymstoku.

Buckley, P.J., Pass, Ch.L., Prescott, K. (1988). Measures of International Competitiveness: A Critical Survey. Journal of Marketing Management, 49(2), 175-200.

Comext-Eurostat (2020). Detailed statistics on international trade in goods (Comext). Retrived from: http://epp.eurostat.ec.europa.eu/newxtweb/mainxtnet.do (access date: 10.09.2020).

Czubak, W., Poczta, W., Rowiński, J. (2019). Struktury obszarowe i ekonomiczne polskiego rolnictwa oraz innych państw unijnych. In: W. Poczta, J. Rowiński (ed.), Struktura polskiego rolnictwa na tle Unii Europejskiej. Warszawa: EFRWP, TEP, CeDeWU.

Dalum, B., Laursen, K., Villumsen, G. (1998). Structural Change in OECD Export Specialisation Patterns: de-specialisation and 'stickiness'. International Review of Applied Economics, $12(3), 423-443$.

De Benedictis, L., Tamberi, M. (2002). A Note on the Balassa Index of Revealed Comparative Advantage. Universita' Politecnica delle Marche Working Paper No. 158. Retrieved from: https://ssrn.com/abstract=289602 (access date: 10.10 .2020$)$.

Eurostat (2020). Agriculture. Retrieved from: https:/ec.europa.eu/eurostat/data/database (access date: 10.09 .2020$)$.

FAOSTAT(2020). Data. Retrieved from: http://www.fao.org/statistics/en/ (access date: 10.09.2020).

Jaroszewska, J., Rembisz, W. (2019). Relacje czynnikowe i produktywnościowe w rolnictwie Unii Europejskiej. Wieś i Rolnictwo, 2(183), 31-55. DOI:10.7366/wir022019/02.

Kennedy, P.L., Harrison, R.W., Kalaitzandonakes, N.G., Peterson, H.Ch., Rindfuss, R.P. (1997). Perspectives on Evaluating Competitiveness in Agribusiness Industries. Agribusiness, 13(4), 385-392.

Kołodko, G.W. (2010). Wędrujący Świat. Warszawa: Wyd. Prószyński i S-ka.

Lafay, G. (1992). The Measurement of Revealed Comparative Advantages. In: M.G. Dagenais, P.A. Muet (ed.), International Trade Modeling. London: Chapman \& Hill.

Laursen, K. (1998). Revealed Comparative Advantage and the Alternatives as Measures of International Specialisation. DRUID Working Paper No. 98-30. Copenhagen: Danish Research Unit for Industrial Dynamics, Copenhagen Business School, Department of Industrial Economics and Strategy.

Lubiński, M. (1995). Konkurencyjność gospodarki: pojęcie i sposób mierzenia. In: M. Lubiński, T. Smuga (ed.), Międzynarodowa konkurencyjność gospodarki Polski - uwarunkowania $i$ perspektywy. Raporty - Studia nad konkurencyjnością. Warszawa: Instytut Rozwoju i Studiów Strategicznych. 
Milczarek, D. (2004). Unia Europejska a globalizacja. Studia Europejskie, 3, 9-27.

Misala, J. (2007). Międzynarodowa zdolność konkurencyjna i międzynarodowa konkurencyjność gospodarki narodowej. Podstawy teoretyczne. Radom: Wydawnictwo Politechniki Radomskiej.

Nosecka, B., Pawlak, K., Poczta, W. (2011). Wybrane aspekty konkurencyjności rolnictwa. Program Wieloletni 2011-2014, nr 7. Warszawa: IERiGŻ-PIB.

Pawlak, K. (2013). Międzynarodowa zdolność konkurencyjna sektora rolno-spożywczego krajów Unii Europejskiej. Rozprawy Naukowe nr 448. Poznań: Wydawnictwo Uniwersytetu Przyrodniczego w Poznaniu.

Pawlak, K. (2014). Zmiany w polskim handlu zagranicznym produktami rolno-spożywczymi po akcesji do Unii Europejskiej. Zeszyty Naukowe $S G G W$ - Problemy rolnictwa światowego, Vol. 14(XXIX), Issue 2, 170-184.

Pawlak, K. (2017). Importance and Comparative Avantages of the EU and US Agri-food Sector in World Trade in 1995-2015. Scientific Journal of Warsaw University of Life Sciences SGGW Problems of world agriculture, Vol. 17(XXXII), No. 4, 236-248.

Pawlak, K. (2018). Comparative advantages of the Polish Agri-Food Sector on the US Market. Proceedings of the 2018 International Scientific Conference "Economic Sciences for Agribusiness and Rural Economy”. Warsaw University of Life Sciences - SGGW, Faculty of Economic Sciences, Warsaw, 7-8 June, 223-230.

Pitts, E., Lagnevik, M. (1998). What Determines Food Industry Competitiveness? In: W.B. Traill, E. Pitts (ed.), Competitiveness in the food industry. London: Blackie Academic \& Professional.

Poczta, W., Pawlak, K. (2010). Potencjał polskiego rolnictwa pięć lat po akcesji Polski do UE jako przesłanka jego konkurencyjności. Wieś i Rolnictwo, 1(146), 21-47.

Poczta, W., Pawlak, K. (2011). Potenzielle Wettbewerbsfächigkeit und Konkurrenzposition des polnischen Landwirtschaftssektors auf dem Europäischen Binnenmarkt. Berichte über Landwirtschaft, 89(1), 134-169.

Seremak-Bulge, J., Łopaciuk, W. (2011). Ogólna ocena polskiego handlu zagranicznego produktami rolno-spożywczymi w latach 1995-2009. In: J. Seremak-Bulge (ed.), Handel zagraniczny produktami rolno-spożywczymi w latach 1995-2009. Studia i Monografie, No. 152, Warszawa: IERiGŻ-PIB.

Skawińska, E. (2002). Reakcje na zmiany a konkurencyjność przedsiębiorstw. In: E. Skawińska (ed.), Konkurencyjność przedsiębiorstw - nowe podejście. Warszawa-Poznań: Wydawnictwo Naukowe PWN.

Smutka, L., Maitah, M., Svatos, M. (2018). Changes in the Czech Agrarian Foreign Trade Competitiveness - Different Groups of Partners' Specifics. Agricultural Economics - Czech, 64(9), 399-411. DOI: 10.17221/399/2016-AGRICECON.

Szczepaniak, I. (2019). Changes in Comparative Advantages of the Polish Food Sector in World Trade. Equilibrium. Quarterly Journal of Economics and Economic Policy, 14(3), 463-480. DOI: $10.24136 /$ eq.2019.022.

The State of Food and Agriculture. Innovation in family farming. (2014). Rome: FAO.

UNCTADstat (2020). Data Center. Retrieved from: https://unctadstat.unctad.org/wds/Report Folders/reportFolders.aspx?sCS_ChosenLang=en (access date: 10.09.2020).

Van Duren, E., Martin, L., Westgren, R. (1991). Assessing the Competitiveness of Canada's Agrifood Industry. Canadian Journal of Agricultural Economics, 39(4), 727-738.

Widodo, T. (2009). Comparative Advantage: Theory, Empirical Measures and Case Studies. Review of Economic and Business Studies, 4, 57-81.

World Bank (2020). Agriculture \& Rural Development. Retrieved from: https://data.worldbank. org/topic/agriculture-and-rural-development?view=chart (access date: 10.09.2020). 
Woś, A. (2000). W obliczu narastającego kryzysu. Warszawa: IERiGŻ.

Woś, A. (2001). Konkurencyjność wewnętrzna rolnictwa. Warszawa: IERiGŻ.

Woś, A. (2003). Konkurencyjność polskiego sektora żywnościowego. Synteza. Warszawa: IERiGŻ. WTO Data Portal (2020). Retrieved from: https://data.wto.org (access date: 10.09.2020).

Wziątek-Kubiak, A. (1997). Problemy oceny konkurencyjności polskiego przemysłu. In: J. Mujżel (ed.), Międzynarodowa konkurencyjność gospodarki polskiej. Raport 30. Warszawa: Rada Strategii Społeczno-Gospodarczej przy Radzie Ministrów.

Wziątek-Kubiak, A. (2003). Konkurencyjność polskiego przemystu. Warszawa: Dom Wydawniczy Bellona. 


\title{
KONKURENCYJNOŚĆ ROLNICTWA POLSKIEGO W KONTEKŚCIE GLOBALIZACJI I INTEGRACJI GOSPODARCZEJ - POTENCJAŁ I POZYCJA KONKURENCYJNA
}

\begin{abstract}
Abstrakt
Celem badań prezentowanych $w$ artykule jest ocena potencjału konkurencyjnego rolnictwa polskiego (konkurencyjności potencjalnej) i pozycji konkurencyjnej zajmowanej przez polski sektor rolno-spożywczy na Jednolitym Rynku Europejskim (JRE) z odwołaniem do kontekstu globalnego. Przeprowadzone badania dowiodty, że rolnictwo polskie dysponuje znaczacym potencjatem produkcyjnym (konkurencyjnościa potencjalna) w skali europejskiej, jednocześnie cechuje się znaczna wadliwościa strukturalna tego potencjału, co może negatywnie wpływać na pozycje konkurencyjna rolnictwa polskiego w przyszłości. Włączenie Polski w obszar JRE i przyjęcie zasad Wspólnej Polityki Handlowej wywołało efekty kreacji i przesunięcia handlu artykułami rolno-spożywczymi, a przewagi komparatywne osiagane na JRE stały się źródłem korzystnej specjalizacji eksportowej i pozwolity na stosunkowo dobre wykorzystanie aktualnie istniejącego potencjału rolnictwa i przemystu spożywczego. Skutkuje to relatywnie dobra pozycja konkurencyjna polskiego sektora rolno-spożywczego na JRE. Jednak $w$ dtugim okresie o zdolności do zachowania lub poprawy konkurencyjności $w$ przyszłości decydował będzie potencjał konkurencyjny. Polski sektor rolno-spożywczy ma znaczny potencjat zwiększania eksportu, wzmacniania swojej pozycji konkurencyjnej (w tym na rynkach pozaunijnych), jednakże pod warunkiem budowy silnych fundamentów sektora, wśród których mieści się poprawa potencjatu konkurencyjnego.
\end{abstract}

Słowa kluczowe: potencjał konkurencyjny, pozycja konkurencyjna, handel zagraniczny produktami rolno-spożywczymi, Unia Europejska, globalizacja.

Accepted for print: 18.12.2020.

Unless stated otherwise all the materials on the website are available under the Creative Commons Attribution 4.0 International license.

Some rights reserved to the Institute of Agricultural and Food Economics - National Research Institute.

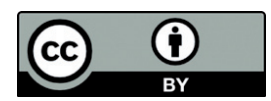

